\title{
Aldose reductase regulates platelet-derived growth factor-induced proliferation through mediating cell cycle progression in rat mesangial cells
}

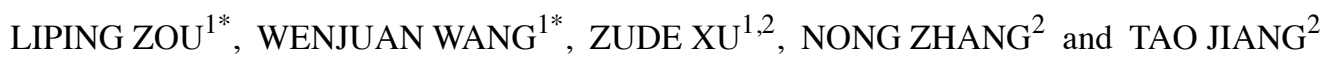 \\ ${ }^{1}$ Department of Pathology, Huashan Hospital, Fudan University, Shanghai 200040; \\ ${ }^{2}$ Department of Pathology, Shanghai Medical College, Fudan University, Shanghai 200032, P.R. China
}

Received January 22, 2012; Accepted April 2, 2012

DOI: $10.3892 / \mathrm{ijmm} .2012 .997$

\begin{abstract}
Aldose reductase (AR), the first and the rate-limiting enzyme of the polyol pathway, has been implicated in plateletderived growth factor (PDGF)-induced proliferation of rat mesangial cells (MsCs). It is well known that AR plays an important role in various chronic diabetic complications, for example, diabetic nephropathy. Moreover, our previous studies have demonstrated that an AR inhibitor (ARI) significantly reduced the proliferation of rat $\mathrm{MsCs}$ induced by PDGF, however, the mechanism remains unclear. The aim of the present study was to elucidate the molecular mechanisms through which AR regulates PDGF-induced rat MsC proliferation. It was demonstrated that PDGF-induced MsC proliferation was significantly inhibited by pretreatment with ARI. Cell cycle analysis by flow cytometry revealed that ARI prevented the entry of cells from the G1 into the S phase. Furthermore, the effect of the PI3K/Akt signaling pathway on the cell cycle was analyzed. The PI3K/Akt pathway was activated with PDGF treatment. However, ARI blocked Akt activation in response to
\end{abstract}

Correspondence to: Dr Tao Jiang, Department of Pathology, Shanghai Medical College, Fudan University, 138 Yixueyuan Road, Shanghai 200032, P.R. China

E-mail: taojiang@fudan.edu.cn

*Contributed equally

Abbreviations: AKR, aldo-keto reductase; AR, aldose reductase; ARI, aldose reductase inhibitor; CDK, cyclin-dependent kinase; $\mathrm{CKI}$, cyclin-dependent kinase inhibitor; ECM, extracellular matrix; GSH, glutathione; GS-DHN, glutathionyl-1,4-dihydroxynonane; HNE, 4-hydroxy-trans-2-nonenal; MAPK, mitogen-activated protein kinase; $\mathrm{MsC}$, mesangial cell; PDGF, platelet-derived growth factor; PDGFR, platelet-derived growth factor receptor; PI3K, phosphoinositide 3 -kinase; ROS, reactive oxygen species; TGF- $\beta 1$, transforming growth factor- $\beta 1$; VSMC, vascular smooth muscle cell

Key words: aldose reductase, platelet-derived growth factor, PI3K/Akt, p21 ${ }^{\text {Cip1 } 1}$, p27 ${ }^{\text {Kipl }}$, mesangial cell
PDGF. Moreover, PDGF increased the levels of $\mathrm{p} 21^{\text {Cip1 }}$ cyclin kinase inhibitor protein in $\mathrm{MsC}$, which was markedly inhibited by pretreatment with ARI. Conversely, PDGF significantly reduced the levels of the $\mathrm{p} 27^{\mathrm{Kip} 1}$ cyclin kinase inhibitor protein, which was also restored by pretreatment with ARI. In conclusion, AR is involved in PDGF-induced rat MsC proliferation, and may serve as a potential target for the inhibition of $\mathrm{MsC}$ proliferation in several types of glomerulonephritis.

\section{Introduction}

Aldose reductase (AR), a member of the aldo-keto reductase (AKR) superfamily, is responsible for conversion of glucose to sorbitol of the polyol pathway in glucose metabolism (1). AR is a cytosolic enzyme and is widely distributed in various tissues and organs such as eye lens, retina, kidney, and reproductive organs. During the past several decades the studies of AR focus on the pathology of long term diabetic complications, including nephropathy, as it plays a pivotal role in the glucose metabolism under hyperglycemia (2-4). However, recent studies indicate that AR functions as not only a metabolizing glucose enzyme but also an enzyme catalyzing the reduction of a wide array of substances including various endogenous and exogenous aldehydes and their glutathione (GSH)-conjugates, phospholipids and steroids (5-7). In addition, it has been shown that AR is associated with cardiac disorders, inflammation, mood disorders and cancers (8-10). Our previous studies also demonstrated that AR was one of the responsive genes for transforming growth factor- $\beta 1$ (TGF- $\beta 1$ ) in cultured mesangial cells. AR has also been confirmed to play a role in extracellular matrix (ECM) deposition and $\mathrm{MsC}$ proliferation mediated by TGF- $\beta 1$ which is a crucial growth factor in glomerulonephritis and glomerulosclerosis, and other growth factors, including platelet-derived growth factor (PDGF) (11).

Abnormal proliferation of $\mathrm{MsCs}$ contributes to the pathogenesis of renal fibrosis and glomerulosclerosis (12). PDGF is generally approved to be a major mitogen for $\mathrm{MsCs}$ and has a high transcription level during both experimental and human glomerulonephritis. Besides, PDGF receptor (PDGFR) mRNA and protein expression are upregulated. Several study reports showed the involvement of PDGF and PDGFR in the proliferation and migration of MsCs (13). Activation of the intrinsic 
tyrosine kinase activity of PDGFR facilitates recruitment of several SH2 domain-containing molecules and associated proteins including the $\mathrm{p} 85$ subunit of phosphoinositide 3-kinase (PI3K), RasGAP and PLC $\gamma 1$. In glomerulonephritis, $\mathrm{MsCs}$ are activated, followed by increased production and release of PDGF into the extracellular space, which activates proliferation of MsCs again as a feedback loop $(14,15)$. Specific antagonism of PDGF suppresses MsC proliferation in vitro, and in experimental glomerulosclerosis (16). Since the effects of $\mathrm{ARI}$ on the inhibition of $\mathrm{MsC}$ proliferation induced by PDGF have been shown, it is possible that AR could be a potential target for alleviating MsC proliferation, and then ECM deposition and glomerulosclerosis.

Although PDGF has a critical role in regulating cell proliferation in several cell types, the related signaling pathways vary among different cells (17). It is known that PDGF binds to a tyrosine kinase receptor which activates a number of downstream pathways, including the mitogen-activated protein kinase (MAPK) family members, PI3K/Akt and many other kinases in MsC $(18,19)$. ARI was recently reported to reduce the phosphorylation of MAPK1/2 in metaplasia of airway epithelial cells and PI3K/Akt in vascular smooth muscle cells (VSMCs) $(20,21)$. However, the PI3K/Akt signaling pathway is one of the most common downstream pathways of PDGF in regulating cell proliferation. Overexpression of dominant negative Akt resulted in complete inhibition of PDGF-induced DNA synthesis in MsC. On the other side, inhibition of MAPK only partially attenuated DNA synthesis (22). In our current study, we confirmed the involvement of the PI3K/Akt pathway in modulating AR-induced inhibition of MsC proliferation.

The mammalian cell cycle is a tightly controlled nuclear event positively regulated by cyclin-dependent kinases (CDKs) and their cyclin-regulatory subunits, and negatively by cyclindependent kinase inhibitors (CKIs). Among the CKIs both $\mathrm{p} 21^{\mathrm{Cip} 1}$ and $\mathrm{p} 27^{\mathrm{Kip} 1}$ contain binding domains for CDK which may intercept the ability of CDK to form active complexes with cyclins, leading to interference with the proliferation of $\operatorname{MsC}(23,24)$.

In this study, we investigated the mechanism by which ARI inhibits PDGF-induced MsC proliferation. We demonstrated that ARI was coupled to attenuation of PI3K/Akt pathway activity in response to PDGF. In addition, our results indicate that ARI arrested PDGF-induced MsC proliferation in the G1 phase through mediating the levels of $\mathrm{p} 21^{\mathrm{Cipl}}$ and $\mathrm{p} 27^{\mathrm{Kip1}}$.

\section{Materials and methods}

Cell culture and reagents. Rat MsCs were obtained by culturing glomeruli isolated from the kidneys of 200-250 g SpragueDawley rats by conventional sieving methods as previously described (25). The cells were cultured in RPMI-1640 medium containing 10\% FBS (Gibco-BRL), $100 \mathrm{U} / \mathrm{ml}$ penicillin, $100 \mu \mathrm{g} / \mathrm{ml}$ streptomycin, and $0.3 \mathrm{~g} / \mathrm{ml}$ sodium pyruvate at $37^{\circ} \mathrm{C}$ in an atmosphere containing $5 \% \mathrm{CO}_{2}$. All experiments were performed using cells between passages 4 and 10 . When the cells reached $60-70 \%$ confluence, the medium was changed to fresh serum-free RPMI-1640 containing $10 \mu \mathrm{M}$ zopolrestat. After $24 \mathrm{~h}$, the cells were stimulated with $20 \mathrm{ng} / \mathrm{ml}$ PDGF-BB for the further investigation. The RPMI-1640 medium was purchased from Invitrogen (San Diego, CA, USA). The ARI zopolrestat was a gift from Pfizer. PDGF-BB was purchased from Sigma Chemical (St. Louis, MO, USA). The wild (HA-Akt) and dominant-negative (HA-Akt-K179A) were generously provided by Dr Boudewijn Burgering (University Medical Center, Utrecht, Netherlands).

MTT assay. The MTT reduction assay was used as a qualitative index of cell viability. After incubation with different compounds as described above, $20 \mu 1$ MTT $(5 \mathrm{mg} / \mathrm{ml})$ (Invitrogen Corp., Carlsbad, CA, USA) was added and cells were cultured for an additional $4 \mathrm{~h}$. Subsequently, cells were lysed using dimethylsulfoxide (150 $\mu \mathrm{l} /$ well) (Pierce Biotechnology, Inc., Rockford, IL, USA). When the formanzan crystals were completely dissolved, the optical density (OD) was measured at $490 \mathrm{~nm}$ using an ELx800 multiwell plate reader (Bio-Tek Instruments, Winooski, VT, USA).

DNA synthesis assay. A colorimetric immunoassay kit Cell proliferation ELISA, BrdU (colorimetric) (Boehringer Mannheim GmbH, Mannheim, Germany) was used for quantification of cell proliferation. This assay is based on the measurement of BrdU incorporation during DNA synthesis. Briefly, the cells were seeded in 96-well plates; pre-incubated for $24 \mathrm{~h}$ with zopolrestat $(10 \mu \mathrm{M})$, and then stimulate with PDGF for another $24 \mathrm{~h}$. They were then labeled with BrdU for $3 \mathrm{~h}$ at $37^{\circ} \mathrm{C}$, washed, and fixed and stained with anti-BrdU antibody for $90 \mathrm{~min}$ at $37^{\circ} \mathrm{C}$. After three washes, the substrate, tetramethylbenzidine, was added, followed by incubation for 30 min. A blocking solution $\left(1 \mathrm{M} \mathrm{H}_{2} \mathrm{SO}_{4}\right)$ was then added, and the absorbance of the samples was measured at $450 \mathrm{~nm}$ with a reference wavelength of $690 \mathrm{~nm}$ using an ELx800 multiwell plate reader (Bio-Tek Instruments).

Flow cytometry. Cell cycle analysis was performed using flow cytometry. After $24 \mathrm{~h}$ of treatment with different compounds, cells were washed twice with phosphate-buffered saline (PBS) and resuspended in $70 \%$ ethanol for $1 \mathrm{~h}$ at $4^{\circ} \mathrm{C}$. Fixed cells were collected by centrifugation, treated with RNase $(25 \mu \mathrm{g} / \mathrm{ml})$ at $37^{\circ} \mathrm{C}$ for $30 \mathrm{~min}$ and stained with propidium iodide $(50 \mu \mathrm{g} / \mathrm{ml})$ at $4^{\circ} \mathrm{C}$ for $30 \mathrm{~min}$ in the dark. The number of cells in the $\mathrm{G} 1$, $\mathrm{S}$ and G2/M phases was analyzed by flow cytometry using a FACSCalibur Flow Cytometer (Becton-Dickinson, San Jose, CA, USA).

Western blot analyses. Cells were cultured and treated as described above, grown to $60-70 \%$ confluence, replaced with serum-free medium for $24 \mathrm{~h}$ and then subjected to PDGF $(20 \mathrm{ng} / \mathrm{ml})$ in the presence or absence of zopolrestat $(10 \mu \mathrm{M})$. Cell lysis was performed on ice with fresh lysis buffer $[1 \mathrm{M}$ Tris (pH 8.0), $2 \mathrm{M} \mathrm{NaCl}, 10 \% \mathrm{NaN}_{3}, 10 \%$ SDS, $10 \%$ NP-40, and $1 \%$ sodium deoxycholate]. All lysates were centrifuged at $15,000 \mathrm{x} \mathrm{g}$ for $10 \mathrm{~min}$ at $4^{\circ} \mathrm{C}$ followed by bicinchoninic acid assay (BCA assay; Pierce Biotechnology, Inc.) to determine protein concentrations. Protein $(40 \mu \mathrm{g})$ was loaded onto 8 or $10 \%$ sodium dodecyl sulfate polyacrylamide gel (SDS-PAGE) and electrophoretically transferred to polyvinylidene fluoride (PVDF). Membranes were blocked for a minimum of $1 \mathrm{~h}$ at room temperature in 5\% bovine serum albumin (BSA) in Trisbuffered saline with $1 \mathrm{ml}$ Tween-20 per liter. The membranes were incubated overnight at $4^{\circ} \mathrm{C}$ with primary antibodies for 
A

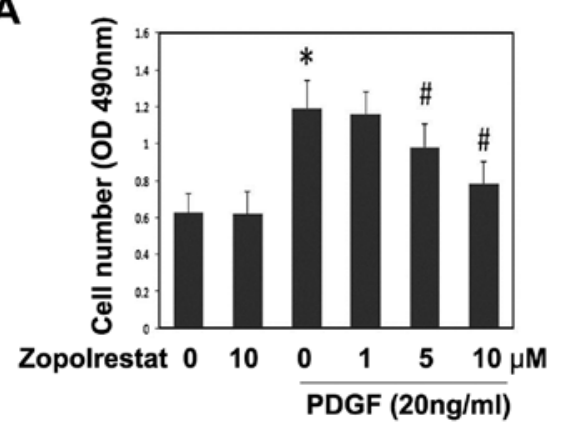

C

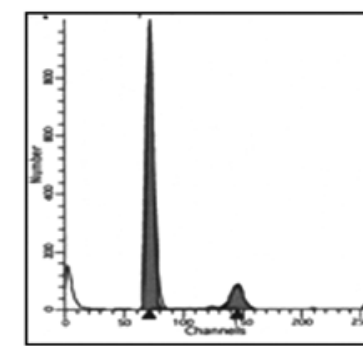

Growth-arrested

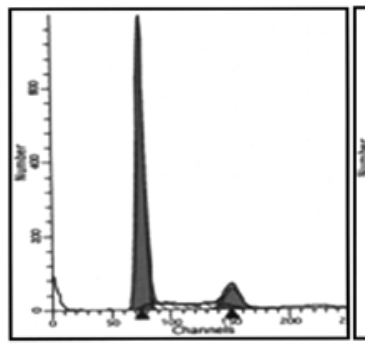

PDGF

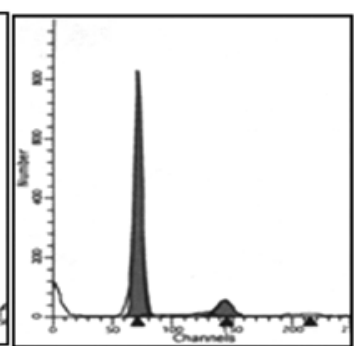

Zopolrestat

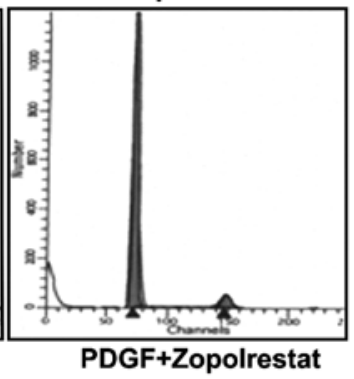

B

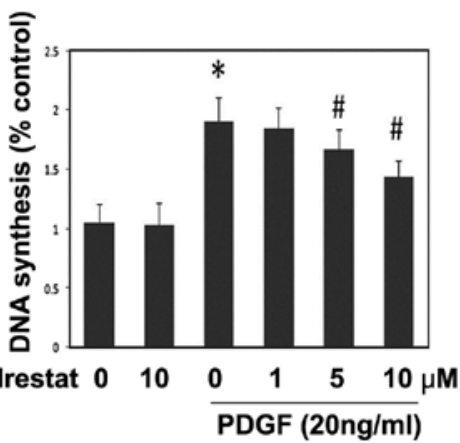

D

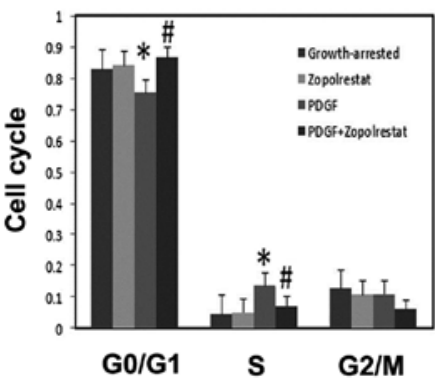

Figure 1. Zopolrestat inhibits G1 cell cycle progression in PDGF-induced mesangial cells. (A) Zopolrestat concentration-dependently suppressed PDGFinduced mesangial cell proliferation. Cells were treated with the indicated concentration of zopolrestat for $24 \mathrm{~h}$ prior to treatment with PDGF ( $20 \mathrm{ng} / \mathrm{ml})$ for another $24 \mathrm{~h}$. Cell proliferation was determined by the MTT assay. Values are the mean \pm SD ( $\mathrm{n}=3$ independent experiments each in triplicate; ${ }^{*} \mathrm{P}<0.05$ vs. control; ${ }^{\text {P }}<0.05$ vs. PDGF). (B) Zopolrestat inhibits PDGF-induced DNA synthesis in mesangial cells. Zopolrestat inhibits PDGF-induced DNA synthesis in a concentration-dependent manner in mesangial cells. DNA synthesis was measured by ELISA according to the manufacturer's instructions. Values are the mean \pm SD. ( $n=3$ independent experiments each in triplicate; ${ }^{*} \mathrm{P}<0.05$ vs. control; ${ }^{*} \mathrm{P}<0.05$ vs. PDGF). (C and D) Zopolrestat inhibits G1-to-S progression in PDGF-stimulated mesangial cells. Synchronized cells were treated with or without zopolrestat (10 $\mu \mathrm{M}) 24 \mathrm{~h}$ prior to stimulation with PDGF (20 ng/ml) for another $24 \mathrm{~h}$. DNA was stained with propidium iodide and assayed by flow cytometry. $\left(\mathrm{n}=3\right.$ independent experiments each in triplicate; ${ }^{*} \mathrm{P}<0.05 \mathrm{vs}$. growtharrested; ${ }^{*} \mathrm{P}<0.05$ vs. PDGF).

p21 (1:500), p27 (1:1,000; all from Santa Cruz Biotechnology, Inc., Santa Cruz, CA, USA), mouse anti- $\beta$-actin (1:1,000; Sigma Chemical), phospho-Akt $(1: 1,000)$, Akt $(1: 1,000)$ (all from Cell Signaling Technology), PDGF $\beta$-receptor subunit (1:1,000; Santa Cruz Biotechnology, Inc.). After being incubated with the respective secondary antibody, immune complexes were detected with ECL Plus (Amersham Biosciences, Piscataway, NJ, USA) on Kodak X-ray film.

Statistical analysis. All the experiments were repeated at least three times independently. Differences were assessed using ANOVA. All values are expressed as mean $\pm \mathrm{SD}$, and statistical significance was defined at $\mathrm{P}<0.05$.

\section{Results}

Effect of zopolrestat on cell proliferation induced by PDGF in rat $M s C$. Mesangial cell proliferation was measured by the MTT assay. Growth-arrested MsCs were treated with or without the ARI zopolrestat in different doses for $24 \mathrm{~h}$ prior to stimulation with PDGF $(20 \mathrm{ng} / \mathrm{ml})$ for another $24 \mathrm{~h}$. The results show that PDGF significantly induced MsC proliferation (Fig. 1A) $(\mathrm{P}<0.05$ vs. control). Pretreatment with zopolrestat alone had no effects on $\mathrm{MsC}$ proliferation (Fig. 1A). However, it inhibited PDGF-induced MsC proliferation in a dose-dependent manner (Fig. 1A) ( $\mathrm{P}<0.05$ vs. PDGF group). To further assess the effect of zopolrestat on DNA synthesis in MsC proliferation, a BrdU cell proliferation assay was performed. PDGF $(20 \mathrm{ng} / \mathrm{ml})$ resulted in an increase in the amount of DNA synthesis, but zopolrestat decreased the DNA synthesis in a dose-dependent manner (Fig. 1B). In contrast, zopolrestat alone did not affect DNA synthesis in MsCs. Our results indicate that zopolrestat treatment inhibited the PDGF-stimulated BrdU incorporation into DNA in MsCs.

In order to further evaluate the effect of ARI zopolrestat treatment upon cell cycle profiles, we then performed flow cytometry. The data showed that PDGF decreased the proportion of cells in the $\mathrm{G} 1$ phase from 82.8 to $75.4 \%$, (Fig. 1C) ( $\mathrm{P}<0.05$ vs. control) 
A
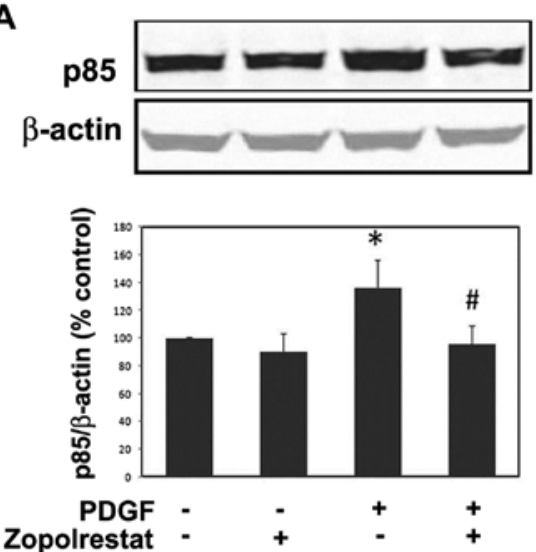

B

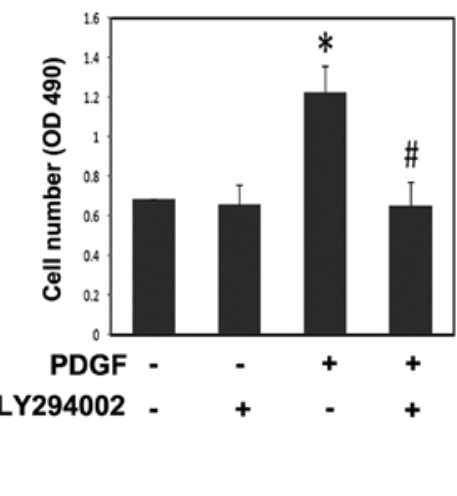

Figure 2. Effects of zopolrestat on p85 protein expression in mesangial cells. Mesangial cells were treated with or without zopolrestat (10 $\mu \mathrm{M}) 24 \mathrm{~h}$ prior to stimulation with PDGF (20 ng/ml). (A) The p85 protein expression was measured by western blotting. (B) Inhibition of PI3K blocks PDGF-induced cell proliferation. MTT analyses were performed. ( $\mathrm{n}=3$ independent experiments each in triplicate; ${ }^{*} \mathrm{P}<0.05 \mathrm{vs}$. control; ${ }^{\#} \mathrm{P}<0.05$ vs. PDGF).

A
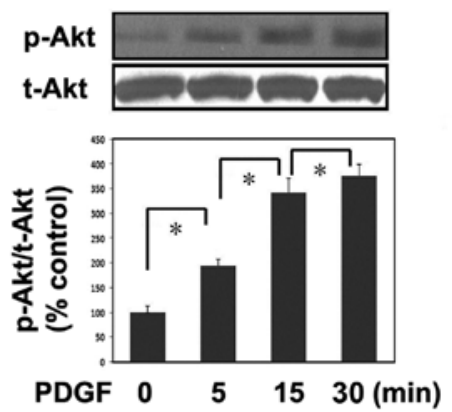

C
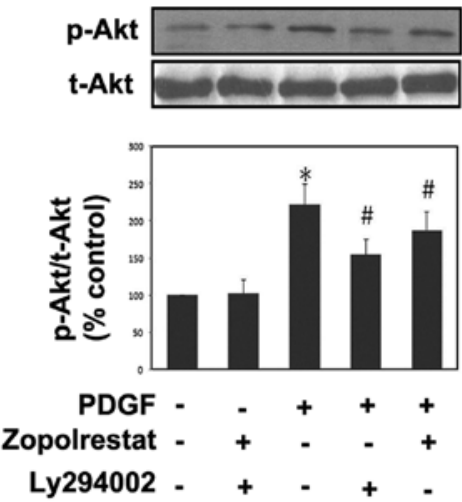

B
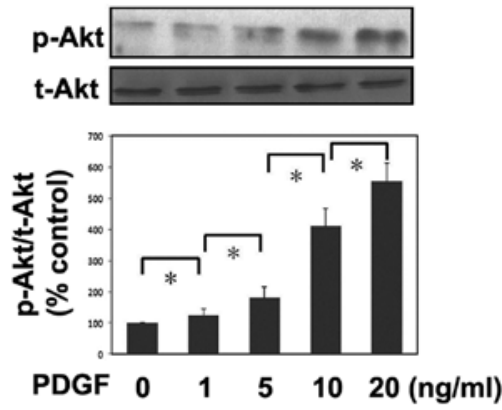

D
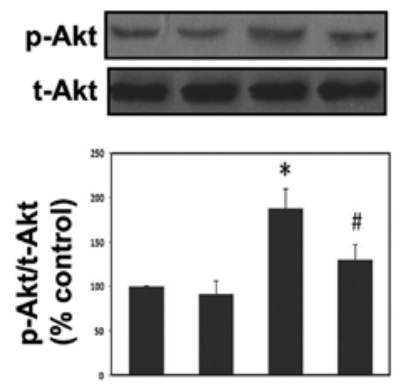

PDGF - $\quad+\quad+$

HA-Akt + - + -

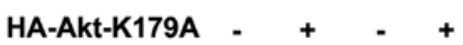

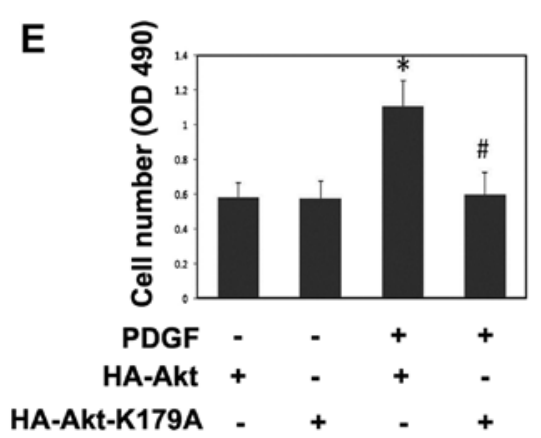

Figure 3. Zopolrestat inhibits the activation of Akt in PDGF-induced mesangial cells. (A and B) Effect of PDGF on Akt activity. (A) Mesangial cells were treated with PDGF $(20 \mathrm{ng} / \mathrm{ml})$ for the indicated periods of time. (B) Mesangial cells were stimulated with the indicated concentration of PDGF for 15 min. (C) Zopolrestat $(10 \mu \mathrm{M})$ reduced the increase of the phosphorylation levels of Akt induced by PDGF $(20 \mathrm{ng} / \mathrm{ml})$. (D) Mesangial cells were transfected with either wild-type (HA-Akt) or dominant-negative form (HA-Akt-K179A) of Akt, serum-starved for $24 \mathrm{~h}$, and then stimulated with or without PDGF for 15 min HA-Akt-K179A blocked the phosphorylation level of Akt induced by PDGF $(20 \mathrm{ng} / \mathrm{ml})$. Western blot analyses were performed from (A) to (D). (E) Dominantnegative form (HA-Akt-K179A) blocks PDGF-induced cell proliferation. MTT analyses were performed ( $\mathrm{n}=3$ independent experiments each in triplicate; ${ }^{*} \mathrm{P}<0.05$ vs. control; ${ }^{*} \mathrm{P}<0.05$ vs. PDGF). 
A

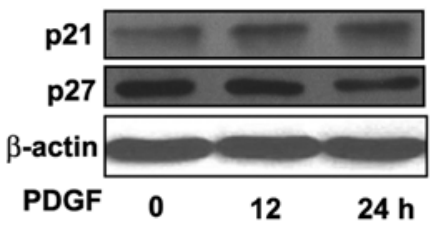

B
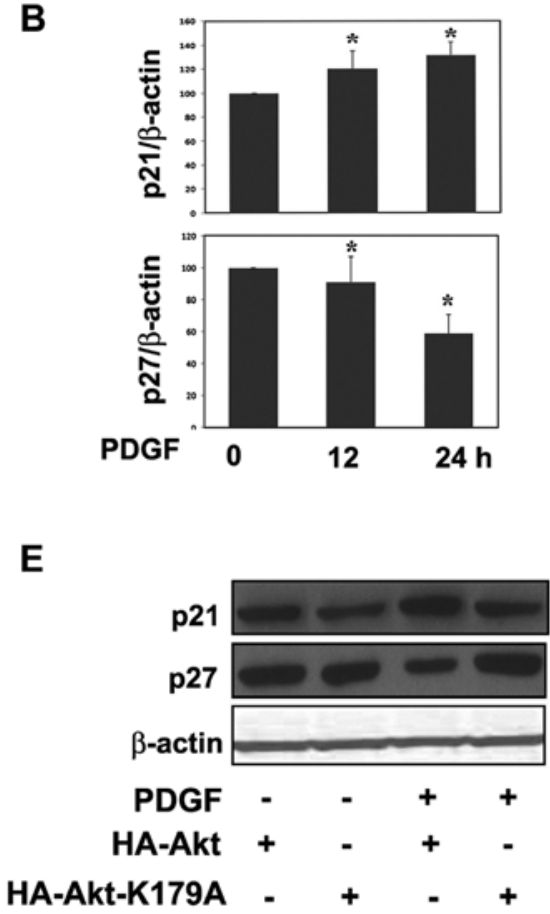

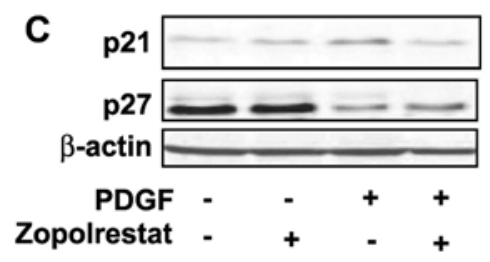

D
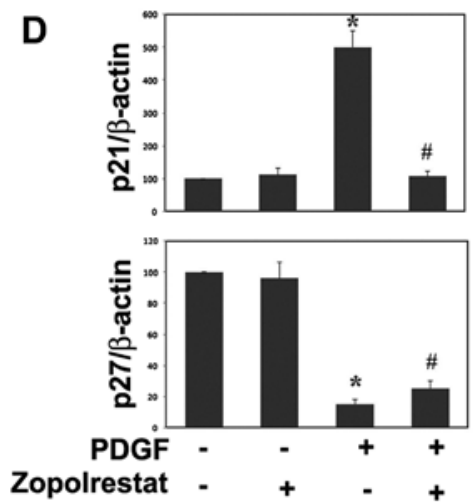

$\mathbf{F}$
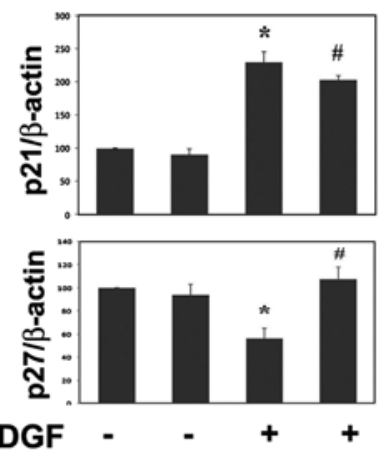

HA-Akt + $+\quad+\quad-$

HA-Akt-K179A - + - +

Figure 4. Zopolrestat reverses the expression level of the cell cycle proteins $\mathrm{p} 21^{\mathrm{Cipl}}$ and $\mathrm{p} 27^{\mathrm{Kipl}}$ induced by PDGF in mesangial cells. (A and B) Time course response of PDGF-induced $\mathrm{p} 21^{\mathrm{Cip} 1}$ and $\mathrm{p} 27^{\mathrm{Kip} 1}$ protein expression in mesangial cells. (C and D) Zopolrestat reversed the changes of the p21 ${ }^{\mathrm{Cipl}}$ and $\mathrm{p} 27^{\mathrm{Kip} 1}$ protein expression induced by PDGF. (E and F) HA-Akt-K179A reversed the changes of $\mathrm{p} 21^{\mathrm{Cipl}}$ and $\mathrm{p} 27^{\mathrm{Kip} 1}$ protein expression induced by PDGF. The protein expression $\mathrm{p} 21^{\mathrm{Cipl}}$ and $\mathrm{p} 27^{\mathrm{Kipl}}$ were measured by western blotting. ( $\mathrm{n}=3$ independent experiments each in triplicate; ${ }^{*} \mathrm{P}<0.05$ vs. control, ${ }^{*} \mathrm{P}<0.05 \mathrm{vs}$. $\mathrm{PDGF}$ ).

and increased that in the $\mathrm{S}$ phase from 4.5 to $13.6 \%$, indicating that PDGF could promote cell cycle progression. In contrast, the pretreatment of zopolrestat increased the number of cells in the G1 phase (from 75.4 to $86.7 \%, \mathrm{P}<0.05$ ) and decreased that in the $\mathrm{S}$ phase (from 13.6 to $7.25 \%, \mathrm{P}<0.05$ ). These results suggest that zopolrestat could block PDGF-induced cell cycle progression by inhibiting the G1-S phase transition and arresting cells in G1.

Effects of zopolrestat on the activation of PI3K induced by $P D G F$ in rat MsCs. Previous studies showed that PI3K activity is necessary for PDGF-induced MsC proliferation (18). Therefore, we examined the effect of ARI on PI3K activity in MsC. PDGF-activated PI3K activity was assessed by measuring the levels of the $\mathrm{p} 85$ regulatory subunit of PI3K. PDGF obviously increased the protein expression of the p85 subunit, while pre-incubation of ARI significantly reduced the p85 subunit activity (Fig. 2A). We then observed that LY294002 (Calbiochem), a specific inhibitor of PI3K, could suppress cell proliferation induced by PDGF (Fig. 2B). We conclude from the above results that PI3K is involved in the inhibition of ARI on PDGF-induced MsC proliferation, and that further studies are warranted.

Effects of zopolrestaton the phosphorylation levels of Akt kinase induced by PDGF in rat mesangial cell. Since the activation of the PI3K/Akt pathway is a key step in the proliferation process of a variety of cell types including MsCs $(18,22)$, western blot analysis was next performed to evaluate the phosphorylation levels of this signaling pathway. The phosphorylation levels of Akt were rapidly induced with time and reached their highest level at about 15-30 min after PDGF stimulation (Fig. 3A). The representative western blots demonstrate that PDGF led to Akt pathway activation in a dose-dependent manner (Fig. 3B). Pre-incubation of the ARI zopolrestat markedly attenuated the induction of PDGF on phospho-Akt, whereas zopolrestat alone had no effects on Akt phosphorylation levels. Meanwhile, we found that LY294002 could downregulate the phosphorylation levels of Akt (Fig. 3C). To closely confirm the role of Akt in PDGF-induced cell proliferation, a dominant-negative mutant of Akt, HA-Akt-K179A, was transfected into MsCs. This 


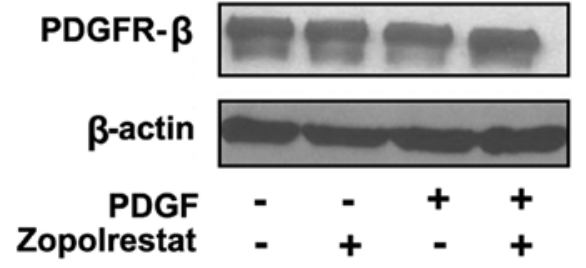

Figure 5. Effects of zopolrestat on PDGFR- $\beta$ receptor protein expression in mesangial cells. Mesangial cells were treated with or without zopolrestat $(10 \mu \mathrm{M}) 24 \mathrm{~h}$ prior to stimulation with PDGF $(20 \mathrm{ng} / \mathrm{ml})$. PDGFR- $\beta$ receptor expression was measured by western blotting ( $\mathrm{n}=3$ independent experiments each in triplicate).

mutant significantly reduced the phosphorylation levels of Akt induced by PDGF (Fig. 3D). In agreement with these findings, we found that HA-Akt-K179A significantly reduced cell proliferation induced by PDGF, indicating a role of Akt in this effect. These results show that the effects of AR inhibition on the PDGF-induced stimulation of mesangial cell proliferation are mediated by the Akt signaling pathways.

Effect of zopolrestat on protein expression of $221^{\text {Cipl }}$ and $p 27^{\text {Kipl }}$ induced by PDGF in rat $M s C$. The levels of the G1 phase CKI $\mathrm{p} 21^{\mathrm{Cip} 1}$ and $\mathrm{p} 27^{\mathrm{Kip} 1}$ in quiescent control and proliferating $\mathrm{MsCs}$ were determined by western blot analysis (Fig. 4). Growtharrested MsCs were treated with or without ARI zopolrestat $(10 \mu \mathrm{M}) 24 \mathrm{~h}$ prior to stimulation with PDGF $(20 \mathrm{ng} / \mathrm{ml})$. Much more appreciable expression of $\mathrm{p} 27^{\mathrm{Kip} 1}$ than $\mathrm{p} 21^{\mathrm{Cip} 1}$ was observed in quiescent control mesangial cells (Fig. 4A). No change in their protein expression levels was observed in zopolrestattreated MsCs. PDGF-treated cells showed an apparent increase in levels of $\mathrm{p} 21^{\mathrm{Cip} 1}$ in a time-dependent manner. The increase of p $21^{\text {Cip1 }}$ was obviously suppressed by co-treatment with zopolrestat or by HA-Akt-K179A mutant cells. In contrast, incubation with PDGF caused an apparent decrease in detectable levels of $\mathrm{p} 27^{\mathrm{Kip} 1}$ in a time-dependent manner; however, the reduction was restored by ARI zopolrestat or by HA-Akt-K179A mutant cells.

Effects of zopolrestat on PDGFR- $\beta$ receptor protein expression. To test whether zopolrestat affects the PDGF-mediated mitogenic signaling cascade at the level of the PDGF receptor, we examined the effects of the ARI zopolrestat on the protein expression of the PDGFR- $\beta$ receptor. Detectable levels of PDGFR- $\beta$ receptor protein expression were expressed in quiescent control cells and no change in their levels was observed in PDGF-treated MsCs with or without pretreatment of zopolrestat (Fig. 5).

\section{Discussion}

In the present study, we demonstrated that ARI partially inhibited the rat $\mathrm{MsC}$ proliferation stimulated by PDGF through modulating the levels of $\mathrm{p} 21^{\mathrm{Cip} 1}$ and $\mathrm{p} 27^{\mathrm{Kip} 1}$. We also confirmed that ARI suppressed the Akt signal pathway in response to PDGF. From these results it was suggested that ARI may has a beneficial role in inhibiting the deterioration of renal function featured with $\mathrm{MsC}$ proliferation and $\mathrm{ECM}$ deposition.
AR, the rate-limiting enzyme in the polyol pathway, was first found to be implicated in the etiology of the diabetic complications apart from its physiological role as osmoregulator in the kidney and supplier for sperm energy $(25,26)$. However, recent reports have demonstrated that, under normal glucose levels, AR may be in involved in various pathological processes other than hyperglycemia as it is a broad-specificity aldo-keto reductase with wide species and tissue distribution (8). Our previous studies showed that AR is one of the responsive genes for TGF- $\beta 1$, regulates TGF- $\beta 1$-induced production of fibronectin and type IV collagen, and participates in PDGFinduced mesangial cell proliferation in cultured rat mesangial cells $(11,27)$. The details of this anti-proliferative mechanism of ARI in mesangial cells are not clear. In this study, we studied the mechanism by which ARI inhibits PDGF-induced $\mathrm{MsC}$ proliferation under normal glucose concentrations. Our study confirmed the role of $\mathrm{AR}$ in regulating $\mathrm{MsC}$ proliferation induced by PDGF, which is consistent with other reports in different cell types induced by distinct growth-related factors $(10,25,28)$.

In our previous studies, we observed that $\mathrm{MsC}$ with $\mathrm{AR}$ overexpression proliferated faster than the controls, which indicated the important role of $\mathrm{AR}$ in $\mathrm{MsC}$ proliferation. We next determined the role of ARI, the specific AR inhibitor, in $\mathrm{MsC}$ proliferation. Consistent with the increased proliferation due to AR overexpression, pretreatment of ARI significantly inhibited $\mathrm{MsC}$ proliferation, which confirmed the regulation of $\mathrm{AR}$ on MsC proliferation (11). However, ARI did not show obvious inhibition for serum-induced MsC proliferation, which is likely due to the fact that there are other growth factors besides PDGF in serum. Previous reports showed that ARI had no effect on PDGF-induced rat aortic smooth muscle cell proliferation under normal glucose conditions (29). Taken together, the effect of ARI on PDGF-induced cell proliferation is cell type-dependent. In this study we further elucidated the molecular mechanism by which ARI arrested PDGF-induced $\mathrm{MsC}$ proliferation. It was confirmed that PDGF-induced cell proliferation was significantly suppressed by pretreatment of ARI while ARI itself had no effects on MsC proliferation. Our results suggest that AR plays a role in PDGF-induced cell proliferation and ARI may be available to be used to protect renal function against mesangial cell abnormally proliferative associated disorders. In addition, our data showed that ARI had no effects on PDGFR- $\beta$ receptor protein expression which is consistent with previous reports $(30,31)$.

The PI3K pathway has been reported to mediate PDGFinduced $\mathrm{MsC}$ proliferation (18). One of the major downstream signaling pathways of $\mathrm{PI} 3 \mathrm{~K}$ is the serine/threonine kinase Akt/PKB. Akt kinase activity is thought to be stimulated by a variety of extracellular signaling factors, including many growth factors and cytokines. The role of Akt related to inhibition of apoptosis has been extensively reported. For example, angiopoietin-1 inhibits endothelial cell apoptosis via the Akt/ survivin pathway (32). Similarly, in RGC-5 retinal ganglion cells imatinib diminishes PDGF-induced Akt phosphorylation to induce apoptosis (33). However, in our study we confirmed the Akt kinase-mediated PDGF-induced DNA synthesis, and more importantly that pretreatment of ARI suppressed it, which is consistent with a previous report in colon cancer cells (34). Our data showed that PDGF activates Akt phos- 
phorylation in a time- and dose-dependent manner, and Akt phosphorylation was significantly reduced after co-treatment with AR or being transfected with HA-Akt-K179A. We demonstrated that ARI blocked Akt phosphorylation triggered by PDGF in MsCs. These data directly link AR to the induction of Akt without hyperglycemia in rat MsC. Although the precise role of Akt in regulating proliferation is unclear, our results indicate that during the process of AR-modulated cell proliferation the altered expression of $\mathrm{p} 21^{\mathrm{Cip} 1}$ and $\mathrm{p} 27^{\mathrm{Kip} 1}$ levels that were observed in PDGF-stimulated cells are coupled to increased levels of Akt kinase phosphorylation. In this study, we confirmed that the AR modulated cell proliferation through the Akt pathway mediating PDGF signaling in $\mathrm{MsC}$, which is in agreement with reports in other studies $(14,35,36)$.

Cell cycle progression CDK inhibitors, in particular those members of the $\mathrm{Cip} / \mathrm{Kip}$ family contribute to cell-cycle regulatory functions. The Cip/Kip family comprise of $\mathrm{p} 21^{\text {Waf1/Cip1 }}$ (p21), p27 ${ }^{\mathrm{Kip} 1}$ (p27) and p57 ${ }^{\mathrm{Kip} 2}$ (p57), which inhibit cyclin-CDK complexes both in the $\mathrm{G} 1$ and $\mathrm{S}$ phases of the cell cycle $(37,38)$. Former reports have demonstrated that $\mathrm{p} 21^{\mathrm{Cip} 1}$ and $\mathrm{p} 27^{\mathrm{Kip} 1}$ are critically involved in cell cycle arrest in $\mathrm{MsC}$ (23). In our experiments PDGF induced the expression of $\mathrm{p} 21^{\mathrm{Cip} 1}$, and this was apparently blocked by ARI or after being transfected with HA-Akt-k179A, which was in agreement with the previous study (39). Increased expression of $\mathrm{p} 21^{\mathrm{Cip} 1}$ during proliferation is observed because it acts as a scaffold to facilitate the assembly of cyclins and CDKs required for DNA synthesis (24). Our data indicate that ARI negatively regulates $\mathrm{p} 21^{\mathrm{Cip} 1}$ expression in $\mathrm{MsC}$. On the other hand, it has been reported that the onset of $\mathrm{MsC}$ proliferation is associated with a reduction in $\mathrm{p} 27^{\mathrm{Kip} 1}$ levels, and in addition, $\mathrm{p} 27^{\mathrm{Kip} 1}$ safeguards against inflammatory glomerular injury in anti-GBM glomerulonephritis (40). To confirm this observation, we found that PDGF greatly downregulated $\mathrm{p} 27^{\mathrm{Kip} 1}$ protein level, and the effect was reversed by pretreatment of ARI or after being transfected with HA-Akt-k179A. It is suggested that $\mathrm{p} 27^{\mathrm{Kip} 1}$ is regulated by ARI in a positive manner. In our experiments PDGF showed contrary effects on $\mathrm{p} 21^{\mathrm{Cip} 1}$ and $\mathrm{p} 27^{\mathrm{Kip} 1}$ expression. It is interesting to note that overexpression of YB-1 led to rat $\mathrm{MsC}$ proliferation by decreasing $\mathrm{p} 21^{\mathrm{Cip} 1}$ expression, but increasing $\mathrm{p} 27^{\mathrm{Kip} 1}$ expression (41). The underlying mechanism of the $\mathrm{p} 21$ and p27 diverse roles in response to different growth factors in the same cell type remains to be explored.

Accumulating evidence has suggested that under normal glucose conditions AR may be upregulated by factors other than hyperglycemia and therefore participate in pathological conditions in non-diabetic disorders. For instance, growth factors cause oxidative stress via generation of reactive oxygen species (ROS) which forms toxic lipid aldehydes such as 4-hydroxy-trans-2-nonenal (HNE) by lipid peroxidation. The final products of HNE catalyzed by AR, glutathionyl-1,4-dihydroxynonane (GS-DHN), transduce inflammatory signaling via a cascade of protein kinases, such as PI3K $(8,9)$. Growth factors-stimulated PI3K may utilize its major downstream Akt kinase signaling pathway for induction of DNA synthesis in MsCs. Our observation would support the importance of the AR/PI3K/Akt/cell cycle protein cascade for the PDGFinduced proliferation of MsCs.

In summary, our data demonstrate that ARI inhibits PDGF-stimulated MsC proliferation via modulation of the
PI3K/Akt pathway which results in alterations in the levels of p21 ${ }^{\text {Cip } 1}$ and $\mathrm{p} 27^{\mathrm{Kip} 1}$. Further studies to elucidate the precise molecular mechanisms by which AR mediates PDGF-induced cell proliferation are currently underway. Future investigation will be needed to determine how AR affects the PI3K/ Akt signal pathway and the expression level of p21 and p27. Understanding this mechanism is potentially important in developing therapeutic strategies to ameliorate mesangial cell proliferative disorders as well as to prevent renal fibrosis.

\section{Acknowledgements}

This study was supported by the National Natural Scientific Foundation of China (NSFC30170430) and the Science and Technology Commission of the Shanghai Municipality (11ZR1402400). We thank Pfizer for generously providing zopolrestat. We are grateful to Dr Boudewijn Burgering for kindly providing us with plasmids.

\section{References}

1. Jez JM, Flynn TG and Penning TM: A new nomenclature for the aldo-keto reductase superfamily. Biochem Pharmacol 54: 639-647, 1997.

2. Anil Kumar P and Bhanuprakash Reddy G: Focus on molecules: aldose reductase. Exp Eye Res 85: 739-740, 2007.

3. Lorenzi M: The polyol pathway as a mechanism for diabetic retinopathy: attractive, elusive, and resilient. Exp Diabetes Res 2007: 61038, 2007.

4. Yabe-Nishimura C: Aldose reductase in glucose toxicity: a potential target for the prevention of diabetic complications. Pharmacol Rev 50: 21-33, 1998.

5. Pladzyk A, Ramana KV, Ansari NH and Srivastava SK: Aldose reductase prevents aldehyde toxicity in cultured human lens epithelial cells. Exp Eye Res 83: 408-416, 2006.

6. Ramana KV, Reddy AB, Tammali R and Srivastava SK: Aldose reductase mediates endotoxin-induced production of nitric oxide and cytotoxicity in murine macrophages. Free Radic Biol Med 42: 1290-1302, 2007.

7. Ramasamy R and Goldberg IJ: Aldose reductase and cardiovascular diseases, creating human-like diabetic complications in an experimental model. Circ Res 106: 1449-1458, 2010.

8. Alexiou P, Pegklidou K, Chatzopoulou M, Nicolaou I and Demopoulos VJ: Aldose reductase enzyme and its implication to major health problems of the 21st century. Curr Med Chem 16: 734-752, 2009.

9. Ramana KV and Srivastava SK: Aldose reductase: a novel therapeutic target for inflammatory pathologies. Int J Biochem Cell Biol 42: 17-20, 2010.

10. Tammali R, Ramana KV, Singhal SS, Awasthi S and Srivastava SK: Aldose reductase regulates growth factor-induced cyclooxygenase-2 expression and prostaglandin E2 production in human colon cancer cells. Cancer Res 66: 9705-9713, 2006.

11. Che Q, Jiang T, Lin YF, Li H and Zhang N: Effects of aldose reductase transfection on the proliferation of rat mesangial cells in vitro. Zhonghua Bing Li Xue Za Zhi 34: 417-420, 2005 (In Chinese).

12. Couser WG: Pathogenesis of glomerular damage in glomerulonephritis. Nephrol Dial Transplant 13 (Suppl 1): S10-S15, 1998

13. Johnson RJ, Floege J, Couser WG and Alpers CE: Role of plateletderived growth factor in glomerular disease. J Am Soc Nephrol 4: $119-128,1993$.

14. Das F, Mahimainathan L, Ghosh-Choudhury N, et al: TGFbeta intercepts nuclear glycogen synthase kinase 3 beta to inhibit PDGF-induced DNA synthesis in mesangial cells. FEBS Lett 581: 5259-5267, 2007.

15. Floege J, Eitner F and Alpers CE: A new look at platelet-derived growth factor in renal disease. J Am Soc Nephrol 19: 12-23, 2008.

16. Gilbert RE, Kelly DJ, McKay T, et al: PDGF signal transduction inhibition ameliorates experimental mesangial proliferative glomerulonephritis. Kidney Int 59: 1324-1332, 2001. 
17. Dirks RP and Bloemers HP: Signals controlling the expression of PDGF. Mol Biol Rep 22: 1-24, 1995.

18. Choudhury GG, Karamitsos C, Hernandez J, Gentilini A, Bardgette $J$ and Abboud HE: PI-3-kinase and MAPK regulate mesangial cell proliferation and migration in response to PDGF. Am J Physiol 273: F931-F938, 1997.

19. Cove-Smith A and Hendry BM: The regulation of mesangial cell proliferation. Nephron Exp Nephrol 108: e74-e79, 2008.

20. Campbell M and Trimble ER: Modification of PI3K- and MAPKdependent chemotaxis in aortic vascular smooth muscle cells by protein kinase CbetaII. Circ Res 96: 197-206, 2005.

21. Yadav UC, Aguilera-Aguirre L, Ramana KV, Boldogh I and Srivastava SK: Aldose reductase inhibition prevents metaplasia of airway epithelial cells. PLoS One 5: e14440, 2010.

22. Choudhury GG: Akt serine threonine kinase regulates plateletderived growth factor-induced DNA synthesis in glomerular mesangial cells: regulation of c-fos AND p27(kip1) gene expression. J Biol Chem 276: 35636-35643, 2001.

23. Marshall CB and Shankland SJ: Cell cycle and glomerular disease: a minireview. Nephron Exp Nephrol 102: e39-e48, 2006

24. Shankland SJ and Wolf G: Cell cycle regulatory proteins in renal disease: role in hypertrophy, proliferation, and apoptosis. Am J Physiol Renal Physiol 278: F515-F529, 2000.

25. Bhatnagar A, Ruef J, Liu S, Srivastava S and Srivastava SK: Regulation of vascular smooth muscle cell growth by aldose reductase. Chem Biol Interact 130-132: 627-636, 2001.

26. Ho HT, Chung SK, Law JW, et al: Aldose reductase-deficient mice develop nephrogenic diabetes insipidus. Mol Cell Biol 20 5840-5846, 2000.

27. Jiang T, Che Q, Lin Y, Li H and Zhang N: Aldose reductase regulates TGF-beta1-induced production of fibronectin and type IV collagen in cultured rat mesangial cells. Nephrology (Carlton) 11: 105-112, 2006.

28. Ramana KV, Chandra D, Srivastava S, Bhatnagar A and Srivastava SK: Aldose reductase mediates the mitogenic signals of cytokines. Chem Biol Interact 143-144: 587-596, 2003.

29. Kasuya Y, Nakamura J, Hamada Y, et al: An aldose reductase inhibitor prevents the glucose-induced increase in PDGF-beta receptor in cultured rat aortic smooth muscle cells. Biochem Biophys Res Commun 261: 853-858, 1999.
30. Ishizawa $\mathrm{K}$, Dorjsuren $\mathrm{N}$, Izawa-Ishizawa $\mathrm{Y}$, et al: Inhibitory effects of adiponectin on platelet-derived growth factor-induced mesangial cell migration. J Endocrinol 202: 309-316, 2009.

31. Schocklmann HO, Lang S, Kralewski M, Hartner A, Ludke A and Sterzel RB: Distinct structural forms of type I collagen modulate cell cycle regulatory proteins in mesangial cells. Kidney Int 58: 1108-1120, 2000.

32. Papapetropoulos A, Fulton D, Mahboubi K, et al: Angiopoietin-1 inhibits endothelial cell apoptosis via the Akt/survivin pathway. J Biol Chem 275: 9102-9105, 2000.

33. Biswas SK, Zhao Y and Sandirasegarane L: Imatinib induces apoptosis by inhibiting PDGF- but not insulin-induced PI 3-kinase/ Akt survival signaling in RGC-5 retinal ganglion cells. Mol Vis 15: 1599-1610, 2009.

34. Ramana KV, Tammali R and Srivastava SK: Inhibition of aldose reductase prevents growth factor-induced G1-S phase transition through the AKT/phosphoinositide 3-kinase/E2F-1 pathway in human colon cancer cells. Mol Cancer Ther 9: 813-824, 2010

35. Mitchell D, Rodgers K, Hanly J, et al: Lipoxins inhibit Akt/PKB activation and cell cycle progression in human mesangial cells. Am J Pathol 164: 937-946, 2004.

36. Venkatesan B, Ghosh-Choudhury N, Das F, et al: Resveratrol inhibits PDGF receptor mitogenic signaling in mesangial cells: role of PTP1B. FASEB J 22: 3469-3482, 2008

37. Shankland SJ: Cell-cycle control and renal disease. Kidney Int 52: 294-308, 1997

38. Sherr CJ and Roberts JM: Inhibitors of mammalian G1 cyclindependent kinases. Genes Dev 9: 1149-1163, 1995.

39. Ghosh SS, Gehr TW, Ghosh S, et al: PPARgamma ligand attenuates PDGF-induced mesangial cell proliferation: role of MAP kinase. Kidney Int 64: 52-62, 2003.

40. Yoshimura A, Nemoto T, Sugenoya Y, et al: Effect of simvastatin on proliferative nephritis and cell-cycle protein expression. Kidney Int Suppl 71: S84-S87, 1999.

41. Feng Q, Huang S, Zhang A, et al: Y-box protein 1 stimulates mesangial cell proliferation via activation of ERK1/2. Nephron Exp Nephrol 113: e16-e25, 2009. 